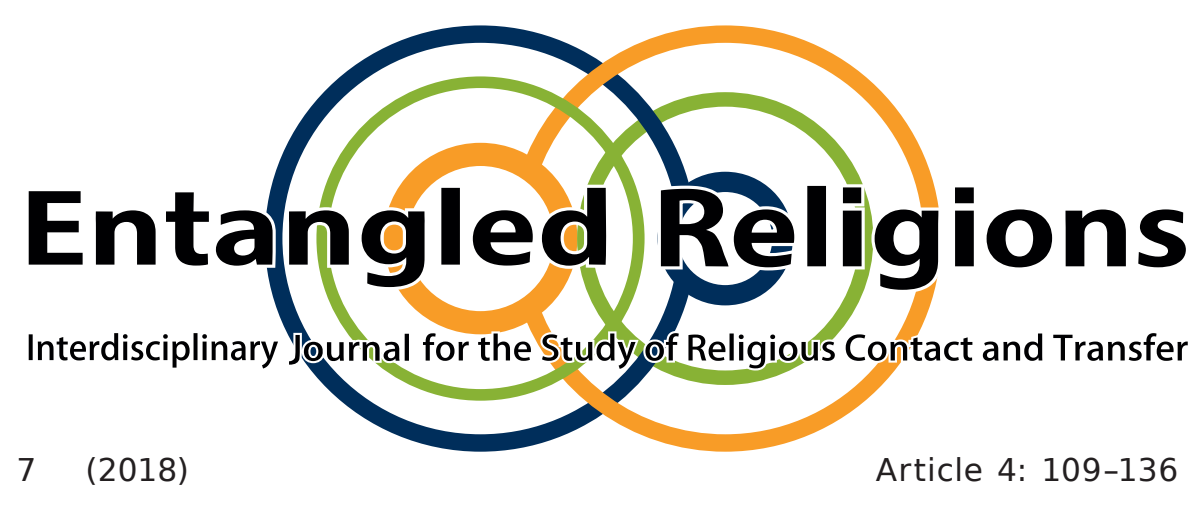

\title{
The Lutheran Church in Rodowo as a Place of the Spiritual Meeting of Three Social Strata
}

\section{PIOTR BIRECKI}

Institute of Art, Nicolaus Copernicus University Torún, Poland

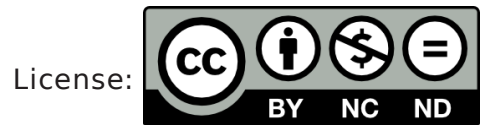

This contribution to Entangled Religions is published under the Creative Commons Attribution-NonCommercial-NoDerivatives 4.0 International Public License (CC BY-NC-ND 4.0 International). The license can be accessed at http://creativecommons.org/licenses/ by-nc-nd/4.0/ or is available from Creative Commons, 559 Nathan Abbot Way, Stanford, California 94305, USA

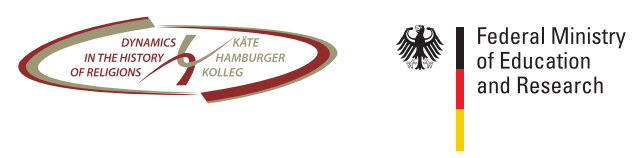




\title{
The Lutheran Church in Rodowo as a Place of the Spiritual Meeting of Three Social Strata
}

\author{
PIOTR BIRECKI
}

Nicolaus Copernicus University Torún

\begin{abstract}
The article presents the hitherto unknown decoration of the furnishing of a little Protestant church in Rodowo in Ducal Prussia, founded by the local aristocratic family of the Schack von Wittenaus. After firstly providing an overview of the complicated confessional history of the region, the church, and its patrons, the second part of this article presents the emblematic decoration of church benches based on the "Four Elements," with models for tapestries designed by Charles Le Brun and published in Paris in 1668 (and later in Germany). The original emblems, with descriptions by Charles Perrault, refer to King Louis XVI as the ideal ruler, but in Rodowo they emphasize the position of the Prussian nobility as the most important social group in the country. The second part of the article presents four unknown easel paintings on the church walls, with a symbolic presentation of Lutheran piety connected with Pietism in Ducal Prussia. The entire artistic ensemble in the church refers to the role of noblemen as leaders in the social and religious life of Ducal Prussia.
\end{abstract}

KEY WORDS Protestant art; Ducal Prussia; emblems; Louis XIV;

Claude Perrault; Charles le Brun; Pietism

This article investigates the artistic programme of the eighteenth-century Lutheran church in Rodowo (now situated in the Northern Polish voivodeship, or administrative unit, of Pomerania) as an idealized image of the order of the three estates (peasants, clergy, and nobles) in Ducal Prussia. It argues that a rather unique set of paintings still visible in the church today had been commissioned and executed as the visualization of the relationship between the clergy, the peasants, and, above all, the Lutheran ruler of the village. The following considerations can only serve as the first attempt to 
analyze the topic. The research presented here is still very much a workin-progress. The article makes some tentative suggestions regarding the visualization of power relations in a village in Ducal Prussia and the influences of popular Western European texts and emblems on this agenda. It contributes to current research on the use of Lutheran church spaces and the iconographic programme commissioned by Lutheran rulers to express their version of the order of society within them. While much recent research has particularly focused on analyzing the redecoration of formerly Catholic churches in the early phase of confessional change, the Lutheran church decorations presented here were commissioned and executed in the mid-eighteenth century (Spicer 2012; Heal 2017: Harasimowicz 2017). The chosen programme therefore sheds further light on the themes employed by patrons and their artists in the age of Pietism and the early Enlightenment. The author hopes to further develop the ideas presented in the following pages through more comparative research in the future.

\section{The History of Rodowo in the Context of Confessional Change in Ducal Prussia}

The Lutheran church in Rodowo, its furnishing, and its iconographic programme have not been the subject of scientific study so far. One of the first aims of this paper must therefore be to present its unique interior to a wider readership. It is unfortunate but symptomatic for many villages in Prussia that we do not have enough sources to write a full history of them, Rodowo included. The village (Ger. Gross Rohdau or Rodau), which was a part of the Prabuty estate, has its roots in medieval times. A first settlement was founded around 1285 and initially belonged (as Radowe) to the Teutonic knight Dietrich Stange and his heirs (Perlbach 1902). 
Other references to the settlement appear in 1323 on the occasion of the demarcation of the neighbouring Gonty village boundaries, and then in 1361, when Bishop Nicholas of Cammin gave a settlement privilege to the village leader, a man named Segehardow, and to the residents of Rodow. The privilege included the right to crop 70.5 fiefs of ground. Rodowo and the church were mentioned in local records concerning land use and land transaction in 1336 and 1361. The site was subsequently destroyed during the Polish-Teutonic wars (1409-1411 and 1454-1466) and, as a consequence, the village and its surrounding area became increasingly depopulated (Kaufmann 1937, 178).

The Reformation was formally introduced in Prussia in 1525 and the Lutheran confession became the confession of the state, which was hence officially called Ducal Prussia. Ducal Prussia was a part of the Teutonic Order's state, divided into two parts: Royal Prussia and Teutonic Prussia (after the war with the Kingdom of Poland in 1466). The Grand Master of the Teutonic Order, Duke Albrecht of Brandenburg-Ansbach, supported by the bishop of Pomesania, Erhard von Queis, who had professed the Lutheran confession even at his installation as bishop in 1523, ordered the secularization of Catholic church lands, including the diocesan headquarters in Prabuty castle (Ger. Riesenburg). Rodowo fell under the rule of Duke Albrecht in 1525. During the Protestant Reformation, Albrecht secularized the order's Prussian territory and, by doing so, also became Duke of Prussia. The Lutheran church established in his duchy was the first Protestant state church to be founded. From then on, Lutheran services were held in the Rodowo parish church. In 1530, the 'Statuta synodalia', a compendium of rules and regulations considered a textbook for the Lutheran confession, was published for the whole territory of Ducal Prussia and the 'Confessio Augustana' was adopted as obligatory (Małłek 2012, 233-247). 
On 13 February 1561, Duke Albrecht issued a new 'Kulmer Law', including a privilege for a certain Jacob Rosteck for 61.5 fiefs of ground, including Rodowo. This privilege was eventually transferred to the next owners of the village, the (probably Lutheran) family of Wenzel Schack von Stangenberg (i.e. from Stążki). The family subsequently changed its name to Schack von Wittenau, i.e. Witenowo in Prussia. From that time onwards, the number of inhabitants in the village and its surrounding properties under the rule of the new owners gradually increased.

Over the following century, the Schack von Wittenaus extended their influence in the area. In 1700, the author of the visitation report of the Catholic Bishop of Chelmno Diocese, Teodor Potocki, who ignored the Protestantization of the country and still claimed spiritual leadership over the territory, noted that Margaretha Schack von Wittenau (1636-1702) had in 1691 incorporated the villages of Balewo, Linki, Cieszymowo, Stążki, Perklice, and Dworek "to the church in Lutheran Rodowo in the Duchy of Prussia". This entry may be indicative of the fact that while the family's primary residence was situated in the neighbouring town of Susz (Ger. Rosenberg), Rodowo was the religious centre of the Schacks' territorial possession. ${ }^{1}$ The Schack von Wittenaus accrued revenues from various positions in the ducal administration and in the Prussian army. In the seventeenth and eighteenth centuries, the family had extensive political, economic, and cultural connections both in Prussia and outside the duchy. Wilhelm Albrecht Schack von Wittenau served as Major General in the armies of the king of Denmark and Norway, Frederick IV, and acted as Colonel of the guards in the army of Denmark. He took part in the wars against Sweden and Holstein on the side of King Frederick IV, probably

1 Visitation of Diocese, Bishop Teodor Potocki, Diocesan Archive in Pelplin, signature 33; the page is not numbered. 
between 1700 and 1720, and fought in Lille, Stralsund, Bonn, and Namur. He highlighted his military successes on his funerary banner in the parish church of Susz, where he displayed fragments of weapons and other military panoply (Kozina and Ostrowski 1992). ${ }^{2}$ The church also showed the painted banners of the Swedish crown and the Duchy of Holstein-Gottorp. Susz parish church, where a gallery of the family's coats of arms are still on display, is a poignant example of the ownership that the new Lutheran rulers had taken of their churches. Wilhelm Albrecht died on 22 May 1731, and from the detailed epitaph inscription in Susz church, we learn that he also fought in the war of Louis XIV against the so-called 'coalition of Augsburg', in the War of Spanish Succession, and in the Third Northern War.

He married Countess Henrietta Sibyl Truchsess von Waldburg, with whom he had five sons: Louis Magnus, Wilhelm Henry, Jan Grzegorz, Fryderyk Benjamin, and Karol Albrecht. The latter, staying mainly in Prussia, founded the new church in Rodowo and invested in the furniture of the church, which was built by his great-grandfather. Karol Albrecht donated the liturgical vessels to Rodowo (Szczepański 2017, 56-58; Klemp 1994, 90). He served as colonel and as major, later as Major General, in the Polish and the Prussian armies. He signed the dissidents' confederation in Torun, and was then elected a delegate to the Polish parliament in 1767/1768. On 14 May 1777, he received the Order of St. Stanislaw established by the Polish king Stanislaw August Poniatowski.

2 A picture of Wilhelm Albrecht Schack zu Wittenau's funerary banner is reproduced in Kozina/Ostrowski 1992, 242. The article provides a rare glimpse into this fascinating display of Lutheran piety in early modern Prussia and Poland. 


\section{The Church in Rodowo}

The new owners of the village took care of the first Catholic and later Protestant wooden church in Rodowo while at the same time investing in church decorations in Susz. In Rodowo, an earlier church building had been attacked during the invasion of Polish troops fighting near Prabuty during the so-called "war of starvation" in 1414. In 1543, the church was described as completely destroyed. We have no information about its appearance or its church furniture, and can only assume that there were fairly long periods when the village had no church at all. No further details are known of the next, probably wooden, church from 1624, mentioned in the Prabuty city financial account books edited in the years 1689/1690 (Kaufmann 1937, 178). The next church, which is the focus of this investigation, was built in 1754 (Fig. 1). In all likelihood, it was of similar shape and had the same dimensions as the previous church. The date of the construction of the new building is preserved on the inscription above the south portal of the church. On the balustrade of the choir, one can read the name "Johann

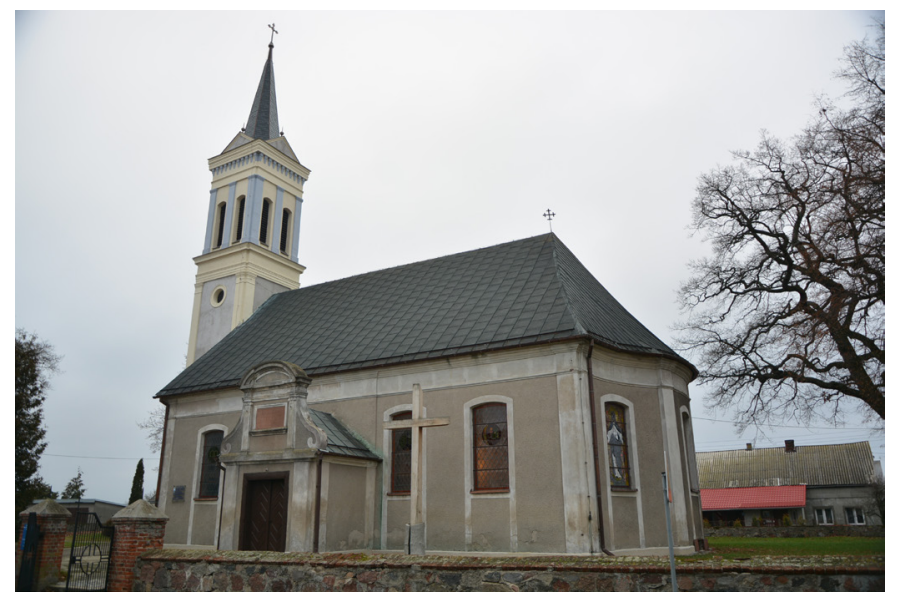

FIGURE 1

Rodowo Church exterior. This and all the following photos were taken by the author. 
Heinrich Selcke", the signature of either the local minister or the carpenter who probably worked on the construction of the church. The originally towerless building was adorned with a tower in 1859, thanks to the efforts of an unknown local parish priest.

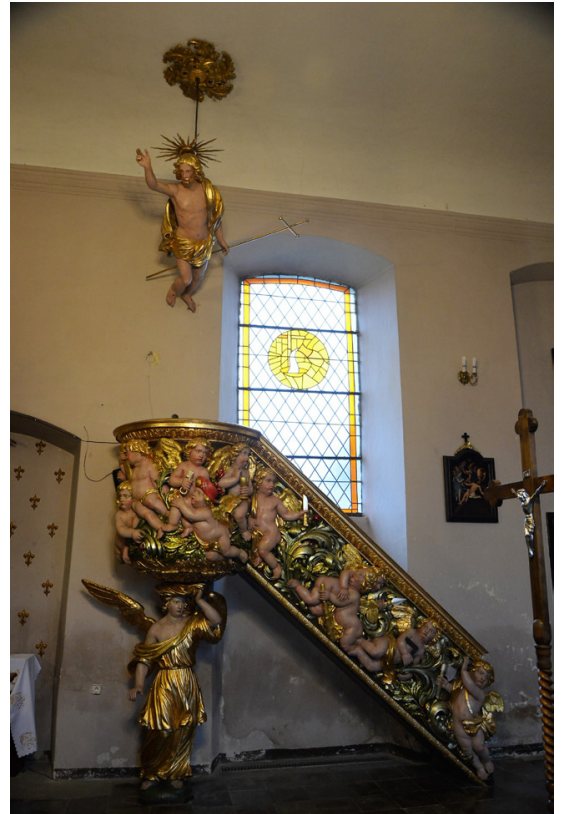

FIGURE 2 Rodau pulpit J. Doebel, Johannes Soeffrens

The architect of the church in Rodowo may also be the architect of a church erected at the same time near Gdakowo. This building was constructed between 1753 and 1755, according to the plans of Bogumił (Gottlieb) Haselbacher, a resident of Gdakowo. He used the plans drawn up by the Royal Prussian master builder Garlineg from Gdańsk (Schmid 1906, 198-201).

The church furniture had not been made for the new church in 1754, but was, in all likelihood, commissioned for the former church and subsequently transferred to the new building. The pulpit, dating back to 1690 , was created in the workshop of the sculptor Johannes Soeffrens the Younger (Ulbrich 1932, 186; Wardzyńska 2014, 141-156; Fig. 2). The hanging baptismal angel can also be traced to his workshop. It must therefore be assumed that the furnishing, which includes the altar, the baptismal font with the baptismal angel, the pulpit with a kind of canopy in the form of a sculpture of the resurrected Christ, and the benches were moved to the new building from the former church. The new gallery was built and the new organ, crowned with figures of Moses, the archangel Michael, and John the Baptist, was perhaps also transferred from the previous galleries in the old church. The family's coat of arms (not retained today), indicating that the church 
furnishing was commissioned by the Schacks, was initially attached to the church benches and was decorated with emblems (Schmid 1906, 197). Additionally, liturgical vessels, ordered in Elblag, indicate by their inscriptions the Schack family's patronage of the church equipment and their role as the guardians of the church. This coat of arms can also be found on the funeral banner in Susz for Albrecht Wilhelm Schack von Wittenau,

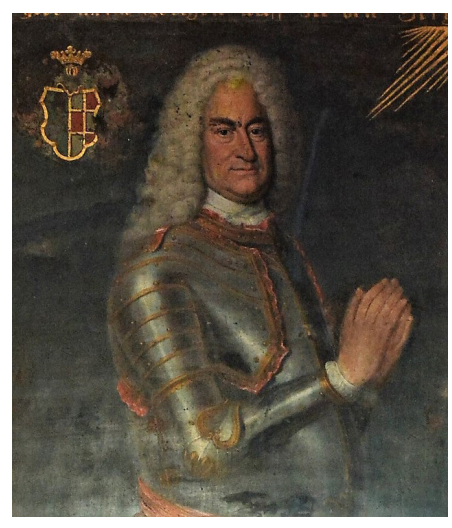

FIGURE 3 Portrait of Schack von Wittenau showing a deep red and blue chessboard and a wolf placed on the red background (Schmid 1906, 197-198; Fig. 3).

\section{The Founders of the Decoration}

Presenting and analyzing the paintings in the interior of the church in Rodowo, we should start with the fact that the ensemble is not completely preserved in its original form. An unknown number of panels with emblematic paintings were presumably stolen. One of them was found in a church in Pasłęk (Preussisch Holland) in the property of the local parish. Given the unique character of the emblem paintings, we can assume that such characteristic decoration benches were made particularly for the church in Rodowo (Fig. 4, 5, 6). So far, the decoration benches have not been discovered in any other churches in Ducal Prussia. Therefore, we will discuss only the panels present there and four oval paintings located in the western part of the church. The decoration of the church in Rodowo can be considered as a visualization of the relationship between the clergy, the peasants, and, above all, the owners of the village. These tiers are represented through different artistic styles and motives, and through the 
different spaces within the church where they were arranged. The piety of the local landlords is visualized in the emblematic decoration, while the paintings refer to the devotion of the rural residents of Rodowo. Each emblem was modified and contains only lemma and imago, without an epigram. The use of emblems in the decorative programme of Lutheran churches has received some scholarly attention in recent years. Mara R. Wade, following the groundbreaking studies of Katarzyna Cieślak, for instance, has carefully analyzed the emblem programme in Lutheran churches in Gdańsk. She and Cieślak diagnose a strong presence of
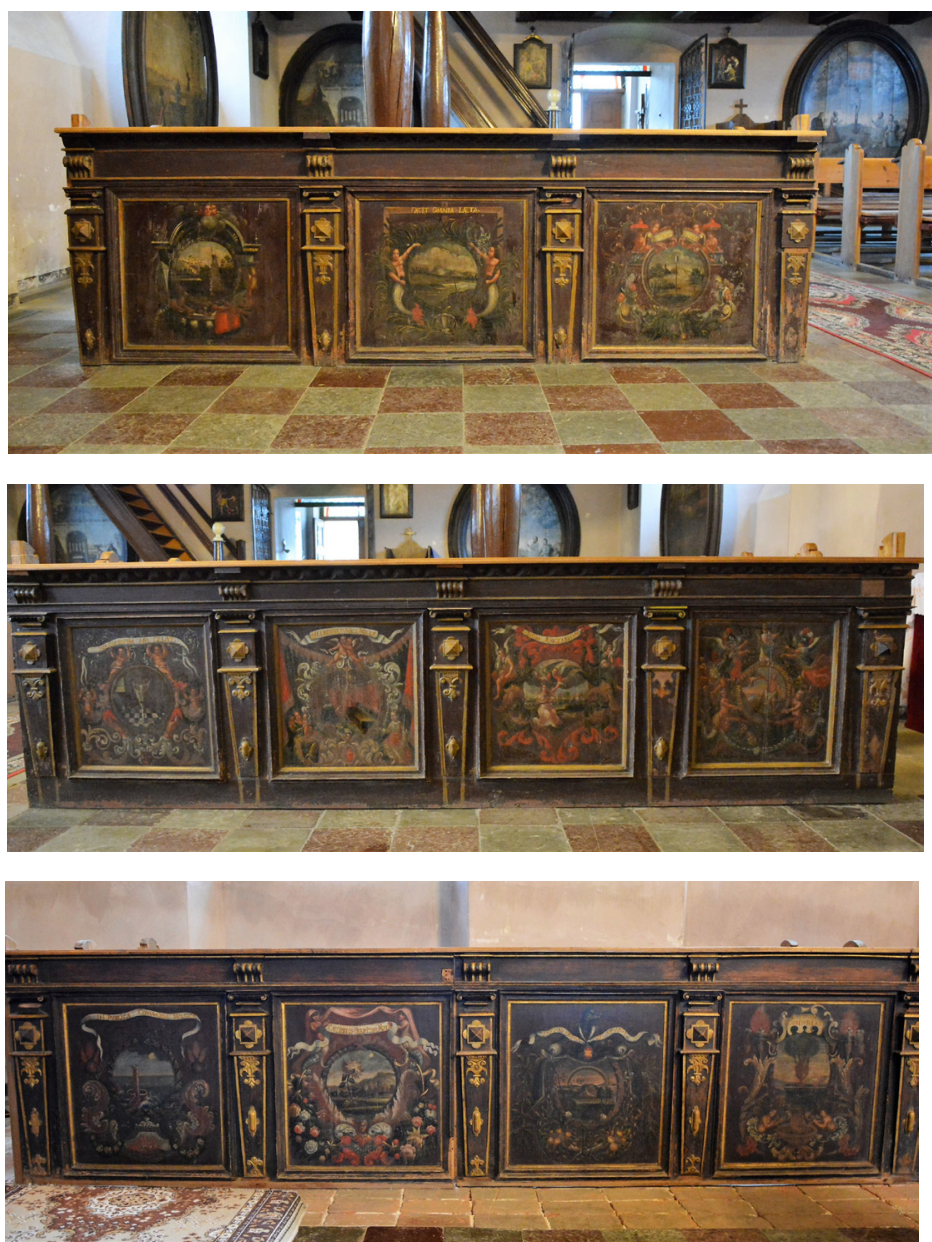

FIGURE 4, 5, 6 Decoration Benches. 
emblematic decorations in the city churches starting in 1639 and persisting until 1694, when the last documented cycle was executed. Thereafter, emblem decorations were occasionally executed in the first two decades of the eighteenth century (Wade 2006; Cieślak 1995).

Far less is known about emblem decorations in smaller village churches, such as Rodowo. Here, both sets of images are exceptional artworks. While emblematic decorations were, and still are, present in Lutheran churches of Ducal Prussia (in Stare Miasto, for example), paintings showing the power of prayer and visualizing the strong personal contact between man and God, as seen in Rodowo, are rare.

\section{The Painted Decoration of the Church Emblems}

What did the Schacks wish to show by commissioning the emblematic decoration of the church benches, and what was the model for these emblems? In the Duchy of Prussia in the present day, due to the absence of studies on Protestant church interiors, paintings with similar themes are unknown. Many of the paintings in larger or smaller towns and villages were destroyed or painted over during the re-Catholicization of the churches after 1945. Epitaphs, paintings of biblical scenes on the galleries, inner ceilings polychrome (Prabuty, Górowo ławeckie, Rychnowo painted by Gottfried Hinz), splendid altars (for instance, in Księży Lasek by Isaac Riga), and painted and decorated carved and sculpted pulpits (Lwowiec, Pasłęk) tend to dominate. Emblematic paintings in small towns and villages are very rarely represented. Besides Rodowo, the Protestant church of Domnovo in Kętrzyn and Bartoszyce parish church are also decorated with emblems. However, these are exceptions. In the churches of former Ducal 
Prussia, other themes dominated in the iconographic programme. These include paintings of personifications of Faith, Hope, and Charity (Sępopol) and images of Luther and Melanchthon (Dźwierzuty, Kętrzyn), but not emblematic images. In line with trends elsewhere in Lutheran churches in early modern Europe, an important detail of Lutheran church decoration were heraldry boards, which were also found in Ducal Prussia churches, for instance in the church in Łabędnik (Birecki 2017). Against the background of local art decorations, both benches and easel paintings in the church in Rodowo are unique in terms of subject matter as well as concerning the graphic patterns used by the artist.

Graphic prototypes, although not yet fully covered in the still incomplete research on Lutheran churches in the Duchy of Prussia, indicate that the creators of the decorations used graphics by Jan Sadeler, Christoph Schwarz, Maarten De Voss, Cornelis Cort, and Maarten van Heemskerck, which were then well-known in Royal Prussia. In Rodowo, at least for part of the compositions, prototypes are based on illustrations taken from the Tapisseries du roy, ou sont representez les quatre elemens et les quatre saisons : avec les devises qvi les accompagnent \& leur explication = Königliche französische Tapezereyen, oder überauss schöne Sinn-Bilder, in welchen die vier Element, samt den vier Jahr-Zeiten, neben den Dencksprüchen und ihren Ausslegungen, vorgestellet. The book, first edited in French by André Félibien in 1670, contained the engravings of a series of famous tapestries made for the court of Louis XIV with accompanying texts, such as poems and mottoes. ${ }^{3}$ The first German editions appeared in Augsburg in 1687 and 1690 by Jacob Koppmayer for Johann Ulrich Krauss. So far, there are no written sources available that might explain the choice

3 A detailed description of the royal tapestries and their interpretation is provided in Bertrand 2007. 
of these prototypes for the Rodowo programme. The commissioners, the Schack family, might have chosen these engravings because they were influenced, as was a great part of the nobility in Ducal Prussia, by the court culture of Louis XIV and might have wanted to display a political and social programme with their choice.

The illustrations were re-engraved (and reversed) from those of Sébastien Le Clerc for the French editions. The two series of four tapestries, each after designs of Charles Le Brun, are depicted in eight double-page engravings. Those for the "Quatre elemens" are signed by Johanna Sybilla Krauss. The thirty-two emblems in the book taken from the tapestry borders were designed by Jacques Bailly. Each is depicted in an engraving after Sebastien Le Clerc, preceded by explanations in French and German prose, and followed by the French verses of Charles Perrault, Jean Chapelin, and others, with German verse translations. In addition to the illustrations, there are added emblems, frontispieces to the two sections on the "Quatre elemens" and the "Quatre saisons", two headpieces, and two decorated initials. All are engraved after Le Clerc. The added emblems are signed by Johann Ulrich Krauss. Apart from the engraved ornaments deriving from the French edition, the book contains woodcut tailpieces and decorated Gothic initials.

The emblems identified among the paintings in the panels of the Rodowo church benches are copies of the interpretations offered by the authors of "Quatre elemens". Taking emblematic designs from the French book describing the four elements and the four seasons shows extrabiblical sources of inspiration present in Lutheran art in Ducal Prussia which move away from the traditional reservoir of forms derived from the Merian Bible and from the Dutch graphic art (Cieślak 1988; Birecki 2009). We can detect, therefore, a new tendency in the iconographic programme, which might have taken place in the eighteenth century. 
The emblems of the "Quatre elemens" indicate the qualities of an ideal ruler. In Rodowo, they emphasize the qualities of the local landlords, the Schack von Wittenaus. The element emblem of "Fire" (Fig. 7), showing the censer of burning fire, refers to the sacred fire burning before God. It represents salvation and the "Holiness of the Lord" ("Gottseligkeit"), who is "a consuming fire" ("Das Heilig Feuhr verzehr"- "Et Sacro capitur igni"). This emblem is associated with the other emblem of "Goodness" or "Gütigkeit", which was explained with the phrase, "My light illuminates the way so that you can sail safely," and was given the motto "In Publica Commod Fulget (pleasantly radiant in public)", indicating that God kindly sends the beacon light to lead man through life's difficulties. "Air" (Fig. 8) is associated with an emblem showing bees flying out of the hive, referring to the explanation of gentleness and grace as qualities that characterize the good ruler: "Gelindigkeit und Gnad, des Königs Zeichen hat". The Lord, as indicated by the explanation, is known by his subjects and by the fact that the king is, analogous to a queen bee, a king bee devoid of a sting. It indicates that he is full of grace and goodness. "Water" is related to the emblem with the motto and explanation of Charles Perrault, "Facit omnia laeta", an illustrated presentation of a water current and figures of frogs, which, in Rodowo, were turned into more serious sirens. The explanation of the emblem placed below the image clearly shows that the majesty of the king will bring good luck and wealth to all who obey him. We can find two examples related to "Earth" in the group of emblems in Rodowo. The first depicts a sunflower in bloom, underlined by the motto, "Wie sich der Himmel regt, so werd ich auch bewegt", explaining to the reader that the power of the king directly affects the subjects, who must follow him just like the sunflower follows the sun. The other emblem says, „Et regit, et Servat," described "Er leitet hin und her, und ist der Schäflein wehr". Charles Perrault explains that the pastoral staff is to watch over the herd 
and, if necessary, to defend it against wolves. The king, therefore, not only governs his people, but also protects them against all enemies.

The emblem ensemble in Rodowo and its particular motifs are unique in Ducal Prussia. In other churches, the nobility preferred to represent themselves and their leadership virtues through a display of their coat of arms. This was easy for the reviewers to read. The Schacks followed this practice in their main church in Susz, but why they preferred this intellectually more ambitious programme of emblems, initially designed

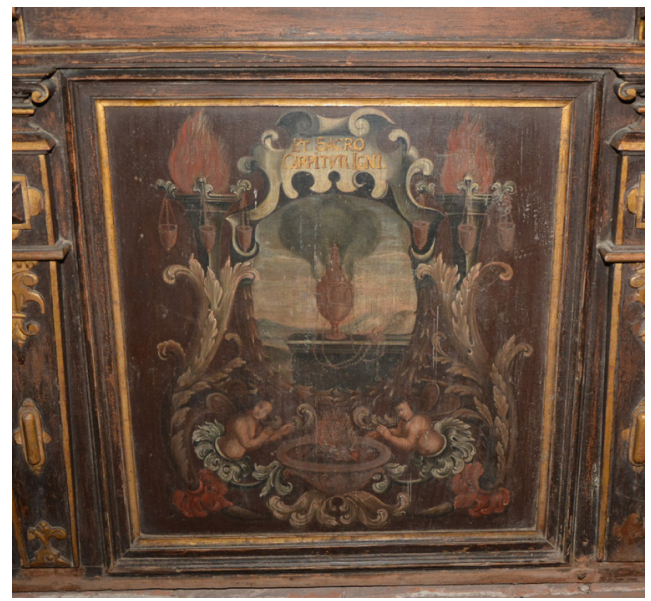

FIGURE 7 Depiction of emblem "Fire".

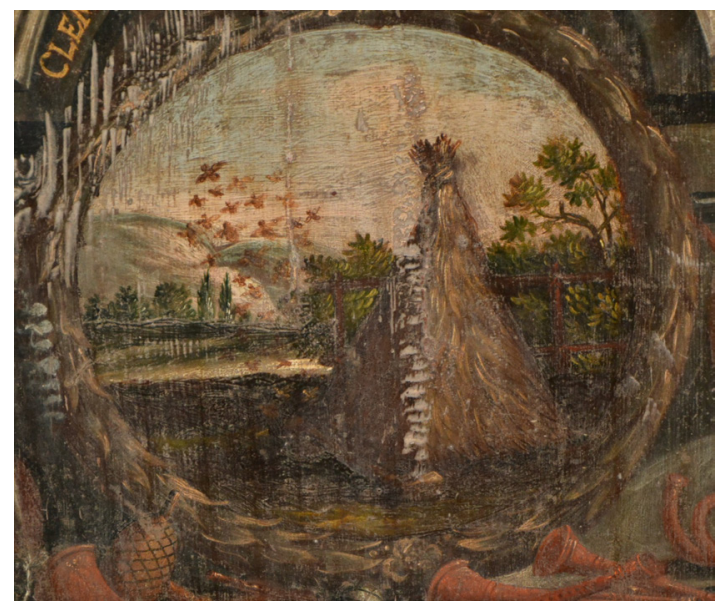

FIGURE 8 Depiction of emblem "Air".

in praise of Louis XIV to decorate their small and remote village church in Rodowo, remains unclear.

\section{Pietism and the Spiritual Meeting of Three Social Strata}

Another very important element of the interior of the church are the four oval paintings (formerly on the ceiling) mentioned above, placed in broad 
frames and hung directly under the galleries in the western part of the church. So far, we have no information about the artist and the workshop where they were made, but it is worth analyzing their content. Three of the paintings relate to prayer as an important element of spiritual life, in which

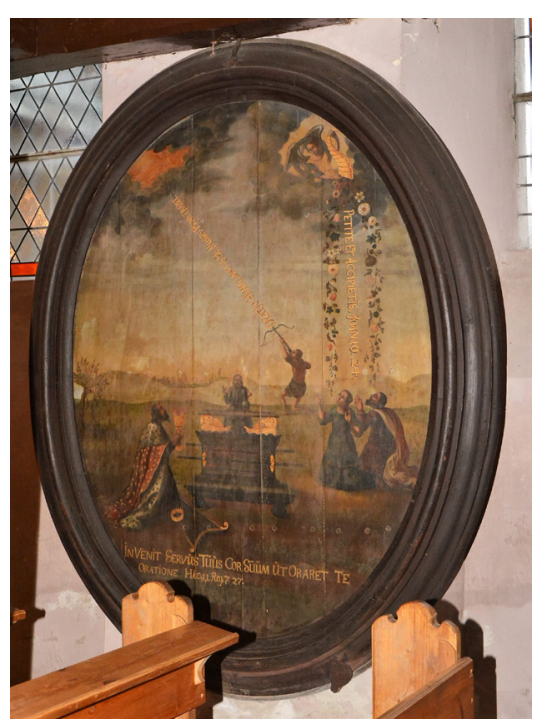

FIGURE 9 The power of prayers. the worship of God stands central. The first painting shows King David at prayer before the Ark of the Covenant (Fig. 9). His prayer is the announcement of the New Testament prayers that go directly to heaven: quia tu, Domine exercituum Deus Israël, revelasti aurem servi tui, dicens: Domum ædificabo tibi: propterea invenit servus tuus cor suum ut oraret te oratione hac.-Reg. 7: 27 / II Samuel 7: 27 /-(For thou, O LORD of hosts, the God of Israel, hast revealed to thy servant, saying, I will build thee an house: Therefore hath thy servant found in his heart to pray this prayer unto thee). What is important in this context is the fact that it is prayer through which those praying receive from God's abundance the grace needed to live: "Petite, et accipietis, ut gaudium vestrum sit plenum" / (Ask and ye shall receive, that your joy may be full; John 16: 24,27). The use of the archer (as a symbol of powerful praying) toward the shining clouds appears to be an incentive to strive consistently towards the grace of God. As the verse quoted here, Ecclesiasticus Oratio humiliantis se nubes penetrabit, comes from the non-canonical book of Sirach, it does not disclose its source. Maybe the prayers of the New Testament are as effective as the one uttered by King David, talking about the construction of sanctuary in Jerusalem, the earthly house of God. 
The second painting directs our attention to spiritual life, evoking the Old Testament prophet Daniel's prayer and grace received from God (Fig. 10). In the Old Testament, God's grace is received through good deeds; in the New Testament, it is obtained freely, by grace through faith. The texts attributed to Daniel (from the book of Daniel chapter 9, v. 9) talk about this: "Tibi autem Domino Deo nostro misericordia et propitiatio, quia recessimus a te" (To the Lord our God belong mercy and

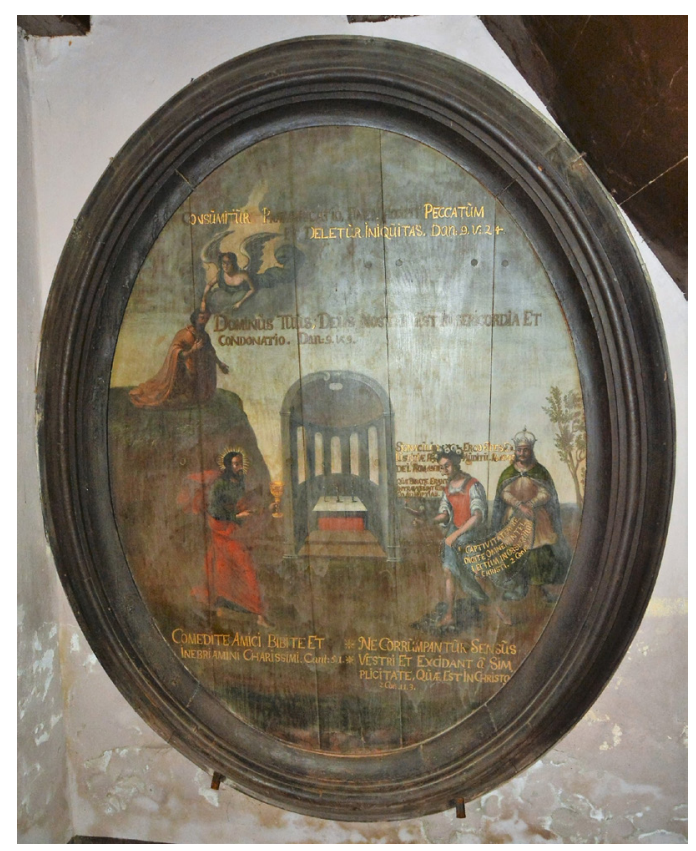

FIGURE 10 The spiritual freedom of man. forgiveness, for we have rebelled against him); and also v. 24: "Septuaginta hebdomades abbreviatae sunt super populum tuum et super urbem sanctam tuam, ut consummetur paevaricatio, et finem accipiat peccatum, et deleatur iniquitas, et adducatur justitia sempiterna, et impleatur visio et prophetia, et ungatur Sanctus sanctorum" (Seventy weeks are decreed about your people and your holy city, to finish the transgression, to put an end to sin, and to atone for iniquity, to bring in everlasting righteousness, to seal both vision and prophet, and to anoint a most holy place). The message here is clear: man can expect mercy and forgiveness if he repents. On the left is Jesus, advancing with the cup, encouraging with words of the Song of Songs "Comedite amici bibite et inebri animi charissimi" (Cant: 5:1) his Bride (Anima Christiana?) to eat Supper, who dethroned in her heart the reign of the king, symbolizing the fleshly manners of the "old man".

The third painting indicates the power of the prayers of the saints (orationes sanctorum), true believers in Christ, whose prayers, usually 
praising God, are carried straight toward heaven (Fig. 11). Prayer for divine power is naturally pronounced by the minister, from the hand-held book, reading: "Sanctus, Sanctus, Sanctus, Dominus, Deus Sabaoth" (Isaiah 6:3). The abortive prayer is spoken in turn by the spouses, whose words, as a thin thread, follow toward earthly mattersexpenditure and revenue books and objects of everyday use, including those used to play cards or musical instruments (the scene explains the inscription under the picture: The true worshippers will worship the Father in spirit and truth, John. 4:23-24, and You ask and receive not: because you ask amiss, James 4:3).

In the church in Rodowo, we are dealing with the efforts of wealthy and educated patrons to present not only the most important truths of the faith (the Lutheran principle of "fides ex auditu" was written on one of the paintings) to their tenants and their guests. The programme of the decorations shows the salvific role of Christ crucified. For Lutheran clergy, these images had a high homiletic potential, allowing the

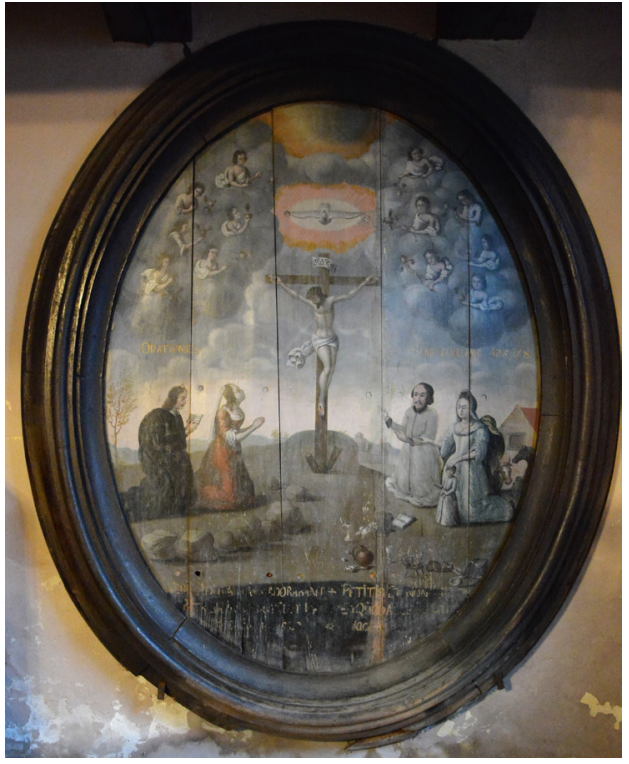

FIGURE 11 The right and wrong pray.

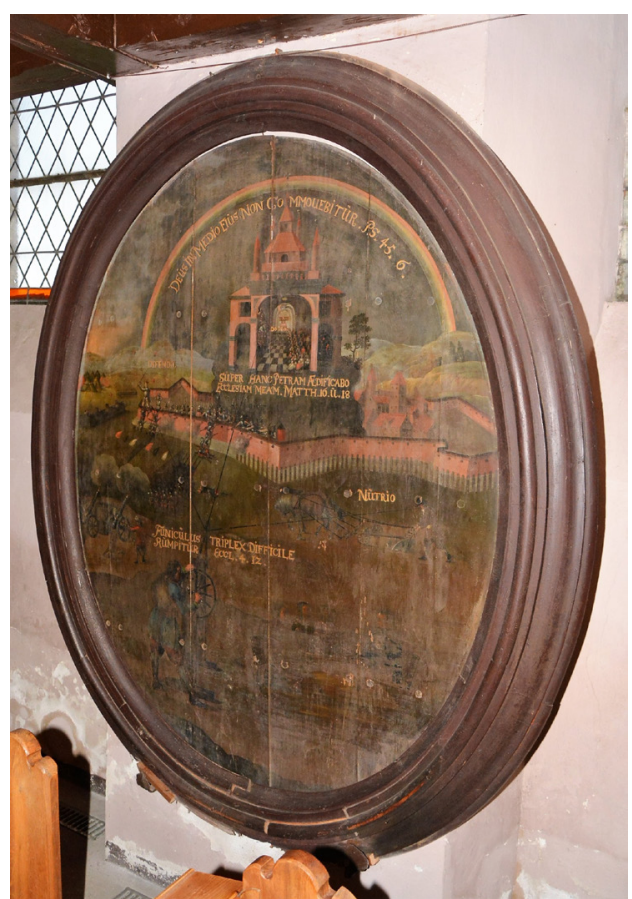

FIGURE 12 The visual structure of society. 
visual display of multiple biblical and social threads in the sermons. The

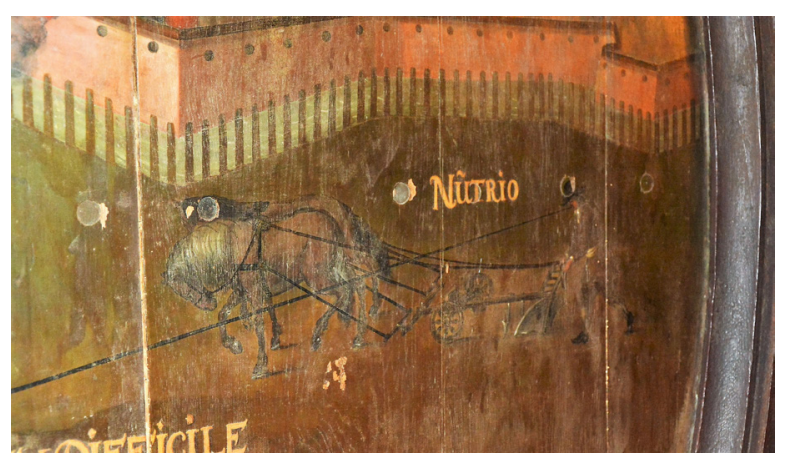

FIGURE 13 The peasant: "Nutricio". emphasis is put on the power of prayer, the grace to meet the Anima Christiania, and, as shown in the fourth painting, the advantages of a stable social order (Fig. 12). The reference to Solomon's triple cord-et si quispiam praevaluerit contra unum duo resistent ei funiculus

triplex difficile rumpitur (and if one prevail against him, two shall withstand him; and a threefold cord is not quickly broken, Eccl. 4: 12)-refers to the strong relationship between a man and a woman and points to the lasting effects of the cooperation between those who defend, who feed, and who pray in the Lutheran church. All these, connected in a cord, will form a durable and permanent community. Therefore, more broadly, the liturgical space of the church in Rodowo consists of three interrelated elements: paintings of prayers, addressing those who work in the fields, i.e. the rural residents (peasants); decoration of the benches, addressing those who defend, i.e. the Schacks; and a unique pulpit, pointing to those who exercise spiritual care (Fig. 13, 14, 15, respectively). That the physical space of the church should also represent a stable social order was already recognized by Martin Luther in his sermon at the opening of the chapel of the castle in Torgau in 1544. The many "Kirchenstuhlordnungen" of the sixteenth

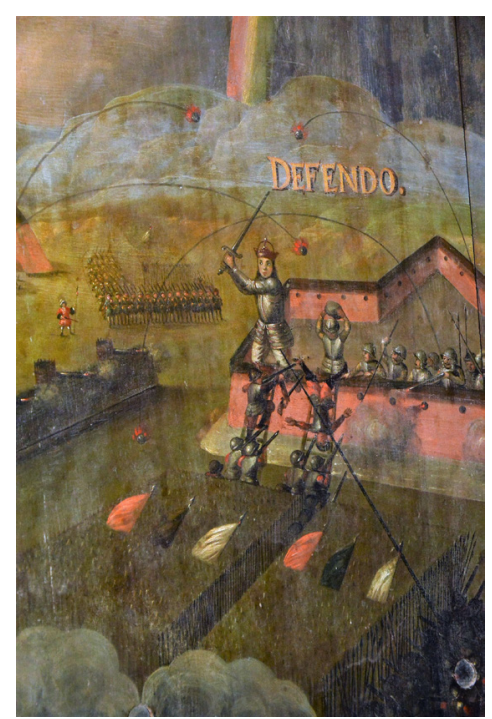

FIGURE 14 The landlord: "Defendo". 
and seventeenth centuries, regulating the seating arrangements of the parishioners and their lords in the church, are visible evidence for the regulatory attempts of the territorial rulers and their Lutheran ministers, which were intended to manifest the leading position of the lords, who were also the spiritual leaders of their flock (Meys 2009, 50-56). The painting programme in Rodowo is vivid evidence of this Lutheran tradition in the use of church space.

A talented, unknown painter (perhaps from the artistic centre of Königsberg) created this cycle of four prayer paintings in Rodowo. He positioned the subtitles freely, rather than within the frames. Subtitles "imprisoned" in frames were very popular in the sixteenth century, in which medieval tradition was maintained (Michalski 1982, 173-174). Positioning inscriptions outside of frames and positioning them directly in the image's background is not unusual in medieval art in the Netherlands up to the end of the sixteenth and the beginning of the seventeenth century (Johann Krell, Anti-Calvinistic Allegory, 15901595, Museum of State History, Leipzig), but the paintings in Rodowo are probably the only

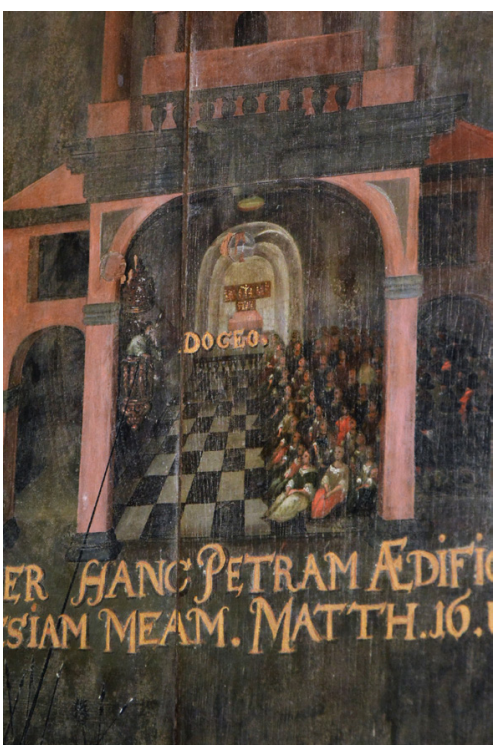

FIGURE 15 The pastor: “Doceo”. example in Ducal Prussia (Michalski 1982, 194). The iconographic source of inspiration is also important. In the case of easel paintings, it is noticeable that the artist based his composition on unknown graphic examples, which may have been amended by the unknown (local?) priest or the patrons of the church. Their visual message, supported by the minister in his sermon, enabled the uneducated people of Rodowo and neighbouring villages belonging to the Schacks to soak up the content of the Bible more easily. 
This is the case with paintings placed on the benches, where the source of inspiration was precisely written emblems and their message was directed toward the most educated members of the parish, that is, the founders or the noble guests of the Schacks visiting the church.

The easel paintings of the church in Rodowo fit into the image of Lutheran art as "verba visibilia" of that religion (Michalski 1982, 173). The emblematic structure is arranged in a very original ensemble, in which the image is completed by the Word. Combining a biblical quotation with a picture is, of course, part of a much older tradition, associated with medieval art, for instance (the words on the bands). In Lutheran art, the coexistence of the image and the written word was realized by inserting biblical verses in medieval paintings, thus literally overwriting the traditional cult of the veneration of sacred images. The last step was giving the words the new confessional narrative. Luther recommended, for instance, the visual representation of the Last Supper "with large golden letters described around, so that the eyes could see, a heart could remember it, and for the reading eyes to praise and thank God" (Michalski 1982, 173-174). Paintings combining inscriptions with images were intriguing iconographic puzzles offering a way to develop multiple biblical threads in preaching on part of the local clergy in Rodowo. An example of this could be a painting showing the king in chains, which might refer to the inner "I", "the old nature" of St. Paul, which, as a king, reigns in humans and must be suppressed in accordance with the accompanying inscription-the will of God.

The tradition of combining images and text in Lutheran culture reminds us of the altar of Gotha by Matthias Gerung from 1530 or the Triptychs of Luther from 1572 by Veit Theim. It draws on the pamphlets criticizing the excesses of the Catholic Church and praising the renewed Lutheran Church (Harasimowicz 1996, 9-19; Burkhardt 2009). There are well-known paintings presenting Lutheran church services, often combining images 
with inscriptions. Important examples of this tradition include the altar in Windsheim from 1601 and the 'Evangelical Sermon and Sacraments' from the epitaph of Johann Jetřich von Žerotína in the church of Holy Trinity in Opočno, (now) Czech Republic, from 1575 (Harasimowicz 1996, 21). We observe the example of combined text and image in the picture directed against Calvinists from the City Museum in Leipzig (painting of John Krell the Younger) from 1590 to 1595 and in the scenes explaining biblical events, such as the scene of Christ's meeting with the Samaritan woman and the rich man and Lazarus from the altar of Mömpelgard (paintings of Heinrich Füllmaurer) from 1540, which shows 157 biblical scenes with appropriate inscriptions. Verses flowing from the mouths and pointing toward heaven can be seen in the textbooks on honorable dying.

In the seventeenth century, emblems were important motifs of decoration in Lutheran church interiors. We find emblems of Daniel Cramer in Pruszcz Gdański and in the iconography of churches in Gdańsk, in St. John and St. Mary, and in Königsberg (Tragheim church, emblems of Daniel Cramer). The use of emblems has also been traced in Lutheran churches in other countries around the Baltic Sea, including in Denmark, Saxony, Thuringia, Schleswig-Holstein, Sweden and Silesia (Höpel and Larsson 2016). In both parts of Prussia, the high period of emblem decorations ends at the same time as it does in other European countries, namely at the end of the seventeenth century; the emblems in Rodowo from the eighteenth century are the last examples of this kind of decoration in Royal and Ducal Prussia (Cieślak 1994, 205-219).

In the small towns in the Duchy of Prussia, the combination of texts and pictures can frequently be seen in pulpits, where biblical verses were placed on the stairs along the railings (e.g. in Łabędnik or in Lwowiec). The paintings with representations of prayers in Rodowo, however, are exceptional both in Prussia and in Protestant Europe. It should be noted 
that paintings depicting of the fervour of prayer and their intended effects, as well as depictions of effective and ineffective prayer, encouraged understanding on part of uneducated Protestant inhabitants of Rodowo and the surrounding area. These images resemble the illustrations of 'True Christianity', the famous four pietistic volumes by Johannes Arndt, whose later editions, such as the 1678/79 print from Riga, were richly illustrated with emblematic images (Wisłocki 2005; Harasimowicz 2017, 236-238).

The book's first chapters are devoted to fervent prayer and its meaning in connecting with God and participation in Christian spiritual transformation. In this case, the paintings are a very good example of fiery spiritual life. Their message was supported by the church architecture itself, which, in its pietistic directory, determined plans for buildings unlike Catholic churches, built on a Latin cross plan. Is it possible that Rodowo was an undiscovered centre of Pietism in the Duchy of Prussia (Harasimowicz 2017)?

\section{Conclusion}

To provide further evidence for the spread of Pietism in Ducal Prussia, more research needs to be undertaken, for instance on the artistic relationships with the pietistic iconography of the paintings in the Old Town near Dzierzgoń, where the decorations of the balcony were based on Pia Desideria of Herman Hugo, and in the cemetery church in Pasłęk (Preussisch Holland), whose paintings were based on Otto van Veen's Amori divini emblemata (Chrzanowski 1994). In the beginning of the eighteenth century, Koenigsberg was one of the centres of expanding Pietism. The Lutheran pastors educated at the Albertina University worked in the parishes of Ducal Prussia. The analysis of the connection between the interior decoration of 
the Rodowo church is the next step for a better understanding of the range of influence of Pietism on this area. On the other hand, the decoration in the church in Rodowo is an interesting example of the influence of French culture in Ducal Prussia and among the local nobility, too. This influence is only apparent in the architecture of the greatest palaces in Prussia, in Drogosze (Jean de Collas), Friedrichstein, and Finckenstein (both projects of Jean de Bodt) (Gawthrop 1993, 200-269; Wójcik 2000; Lorck 1965, 106 107; Dohna 1995, 93).

The images on the benches and on the four great paintings are the kind of message sent by the owners of Rodowo village to the peasant population about their respective status in life: the rulers should follow the rules as set down in the emblems, and the peasants should learn how to pray properly; they also received a visual model of social structure. The preachers had reminders of their sermons written on the walls. The images demonstrate the relationship between the Lutheran lord, his peasants, and the local pastor. In Ducal Prussia, only in Rodowo did the local nobles create such strong lines of communication.

\section{References}

Bertrand, Pascal-Francois. 2007. "Tapestry production at the Gobelins during the reign of Louis XIV, 1661-1715." In Tapestries on the Baroque. The threat of splendour, edited by Thomas P. Campbell, 341-356. New Haven: Yale University Press.

Birecki, Piotr. 2009. "Pierwowzory graficzne w sztuce reformacji toruńskiej." Acta Universitatis Nicolai Copernici. Konserwatorstwo i Muzealnictwo 35: 41-53. 
———. 2017. "Architektura i sztuka na terenie Prus Książęcych (15251657)". In W 500-lecie Reformacji (1517-2017). Z dziejów Kościołów ewangelickich w dawnych Prusach Królewskich i Książęcych, II, tereny dawnych Prus Książęcych, edited by J. Kłaczkow, G. Jasiński, and P. Birecki, 80-138. Toruń: Adam Marszałek Press.

Burkhardt, Johannes. 2009. Stulecie reformacji w Niemczech (15171617). Między rewolucją medialną a przełomem instytucjonalnym. Warszawa: Wiedza Powszechna Press.

Chrzanowski, Tadeusz. 1994. “Kościół w Starym mieście pod Dzierzgoniem pw. św. Apostołów Piotra i Pawła - emblematyka w służbie protestantyzmu." In Sztuka Prus XIII-XVIII wieku, edited by Michał Woźniak, 199-226. Toruń: University Press.

Cieślak, Katarzyna. 1988. "Pierwowzory graficzne epitafiów obrazowych w Gdańsku a problemy ich ikonografii." Biuletyn Historii Sztuki 3: 201-224.

_-_. 1994, "Emblematyka w XVII-wiecznych wnętrzach kościelnych Gdańska." In Sztuka XVII wieku w Polsce, edited by Teresa Hrankowska, 205-219. Warszawa: Arx Regia Press.

-_-. 1995. “Emblematic Programmes in Seventeenth-Century Gdańsk Churches in the Light of Contemporary Protestantism: an Essay and Documentation." Emblematica: An Interdisciplinary Journal for Emblem Studies 9 (1): 21-44.

Dohna, Hermann Graf zu. 1995. “Finckenstein - Kamieniec." In Ostpreußische Gutshäuser in Polen, edited by Kamila Wróblewska, 93. München: C. H. Beck Verlag.

Gawthrop, Richard. 1993. Pietism and the making of eighteenth century Prussia. Cambridge: University Press.

Harasimowicz, Jan. 1996. Kunst als Glaubensbekenntnis. Baden-Baden: Valentin Koerner Verlag. 
-_-. 2017. Sichtbares Wort. Die Kunst als Medium der Konfessionalisierung und Intensivierung des Glaubens in der Frühen Neuzeit. Regensburg: Schnell \& Steiner.

Heal, Bridget. 2017. A Magnificent Faith. Art and Identity in Lutheran Germany. Oxford: Oxford University Press.

Höpel, Ingrid, and Lars Olof Larsson, eds. 2016. Emblematik im Ostseeraum - Emblematics around the Baltic. Kiel: Verlag Ludwig.

Kaufmann, Karl Josef. 1937. Geschichte der Stadt Rosenberg in Westpreussen. Rosenberg: City Press.

Klemp, Aleksander. 1994. Protestanci w dobrach prywatnych w Prusach Królewskich od drugiej połowy XVII do drugiej połowy XVIII wieku. Gdańsk: Ossolineum Press.

Kozina, Irma, and Jan K. Ostrowski. 1992. “Grabfahnen mit Porträtdarstellungen in Polen und in Ostpreußen." Zeitschrift für Kunstgeschichte 55 (2): 225-255.

Lorck, Carl von. 1965. Landschlösser und Gutshäuser in Ost- und Westpreussen. Frankfurt am Main: Veidlich Verlag.

Małłek, Janusz. 2012. "Początki protestantyzmu w Prusach Książęcych." In Opera Selecta, vol. IV, edited by Maria Dąbrowska, 233-247. Toruń: University Press.

Michalski, Sergiusz. 1982. "Widzialne słowa sztuki protestanckiej." In Słowo i Obraz, edited by Agnieszka Morawińska, 151-170. Warszawa: Polskie Wydawnictwo Naukowe.

Meys, Oliver. 2009. Memoria und Bekenntnis. Die Grabdenkmäler evangelischer Landesherren im Heiligen Römischen Reich Deutscher Nation im Zeitalter der Konfessionalisierung. Regensburg: Schnell \& Steiner. 
Perlbach, Max. 1902. “Zur Geschichte des ältesten Großgrundbesitzes im Deutschordenslande Preussen: Dietrich von Dypenow und Dietrich Stange.“ Altpreussische Monatsschrift 39: 78-124.

Schmid, Bernhard. 1906. "Gr. Rodau“. In Die Bau- und Kunstdenkmäler der Provinz Westpreussen: Der Kreis Rosenberg, edited by L. Sauniers, 198-201. Danzig: Kommissions Verlag.

Spicer, Andrew. 2012. Lutheran Churches in Early Modern Europe. Farnham: Ashgate.

Szczepański, Łukasz. 2010. "Życie i kariera wojskowa generała majora Wilhelma Albrechta Schack von Wittenau." Suski Słownik Biograficzny, 56-62. Accessed 11 September, 2017. http:// docplayer.pl/43206697-Zycie-i-kariera-wojskowa-generalamajora-wilhelma-albrechta-schack-von-wittenau.html.

Ulbrich, Anton. 1932. Kunstgeschichte Ostpreussens. Frankfurt am Main: Verlag Weidlich.

Wardzyńska, Katarzyna. 2014. "Johannes Soeffrens (1660-po 1721) rzeźbiarz niderlandzki w Elblągu. Wstęp do monografii.“ Porta Aurea 13: 136-160.

Wade, Mara R. 2006. "Sebald Meinhard's Liturgical Emblems in Danzig." In The Emblem in Scandinavia and the Baltic, edited by Simon McKeown, and Mara R. Wade, 205-230. Glasgow: Glasgow University Press.

Wallis, Mieczysław. 1971. “Napisy na obrazach.” Studia semiotyczne: 39-64. 
Wisłocki, Marcin. 2005. “Der Einfluss Johannes Arndts und der verinnerlichten Frömmigkeitsrichtung des 17. Jahrhunderts auf die kirchliche Kunst im südlichen Ostseeraum. “ In Interdisziplinäre Pietismusforschungen. Beiträge zum ersten Internationalen Kongress für Pietismusforschung 2001, edited by U. Sträter, H. Lehmann, Th. Müller-Bahlke, and J. Wallmann, 375-389. Tübingen: Verlag der Franckeschen Stiftungen im Max Niemeyer Verlag.

- - - 2006, "From Emblem Books to Ecclesiastical Space; Emblems and Quasi-Emblems in Protestant Churches on the Southern Coast of Baltic Sea and their Devotional Background." In The Emblem in Scandinavia and the Baltic, edited by Simon McKeown, and Mara R. Wade, 263-294. Glasgow: University Press.

Wójcik, Dagmara. 2000. “Ze studiów nad programem ideowym kościoła w Starym Mieście pod Dzierzgoniem." In Sztuka i dialog wyznań, edited by Jan Harasimowicz, 325-336. Warszawa: EJKO Press. 